Covered in: Web of Sciences (WOS); EBSCO; ERIH+; Google Scholar; Index Copernicus; Ideas RePeC; Econpapers; Socionet; CEEOL; Ulrich ProQuest; Cabell, Journalseek; Scipio; Philpapers; SHERPA/RoMEO repositories; KVK; WorldCat; CrossRef; CrossCheck

\section{Forms of Inequality Manifestation in Continuous Training Perceived by Teachers}

\section{Roxana Constanţa ENACHE ${ }^{1}$, Maria GOGA ${ }^{2}$}

${ }^{1}$ Assoc. Prof. Ph.D., Technical University of Civil Engineering Bucharest, Romania, rocatare@yahoo.com, +40-741739594

${ }^{2}$ Technical University of Civil Engineering Bucharest, Romania.
Abstract: European tendencies are felt faster and more intensely in all areas of the Romanian socio-cultural system, especially after Romania's entry in the European Union. We are talking more and more about them, we are concerned about them and act accordingly in the education domain where, especially for planning and designing, we are proposing transformations - especially in the continuous training programs. In this paper we aim to identify ways of manifesting inequality in education - as perceived by teachers in continuous training programs. We used quantitative analyses with the teachers involved in continuous training. This questionnaire has helped us to outline main forms of manifestation of inequalities in continuous training and teachers' perceptions of them, as well as to identify ways to prevent and combat this phenomenon. The most important inequalities in lifelong learning are: inefficient communication that does not give them access to information on continuous training programs; financial resources to sustain continuous training; lack of teachers' competencies in reflexive practice and research methodology as ways of continuous training; prejudices, discrimination, etc. This article presents the main inequalities in the training system of teachers in Romania, as well as general guidelines for the development of policies and practices in this field.

Keywords: teachers' perceptions; inequality; continuous training programs.

How to cite: Enache, R.C., \& Goga, M. (2019). Forms of Inequality Manifestation in Continuous Training Perceived by Teachers. Revista Romaneasca pentru Educatie Multidimensionala, 11(3), 11-19. doi:10.18662/rrem/135 


\section{Introduction}

Changes in education and society impose new demands on teachers. Teachers are required to develop transversal competences, which is a new category of skills to prepare their socio-professional insertion into knowledge, and technology society that needs postmodern teaching methods. Teachers are increasingly confronted with classes that have diverse pupils of different cultures and languages, with different levels of skills and needs, which implies the achievement of an integrated, intercultural education. Teachers should use the possibilities offered (European Council, 2009) by new technologies and respond to the need of individualized learning; they may also have to undertake additional decision-making and management tasks resulting from the increased autonomy of schools. This can be achieved through the specialized training of teachers. Therefore, teachers face situations for which they are not trained either through initial training or through continuing training programs, lacking specific skills required by daily educational situations.

\section{Continuous Teacher Professional Development in EU - Benefits and Limits}

Initial and continuous professional development of teachers has been a priority of European and Romanian educational policies for more than 20 years, involving changes in both educational practice and specialized work. The source of inequality in education is the initial training that offers different competences to the teachers (European Commission, 2015) and the continuous training is in the same situation, although there are advantages in the sense that each teacher chooses the training program in which s/he wants to achieve performance, this leading to inequality in the development of categories of competencies.

Other issues (European Commission, 2015) that may lead to inequalities in education at EU level may be a low level of investment in continuing teacher education and development, as:

- workplace training is mandatory in only some Member States;

- if there is training at work, it is usually at the level of not more than 20 hours annually in not more than 5 days. 


\subsection{Distinctive marks of continuing professional development (CPD) at European level}

With reference to the field of continuous training, we consider the following aspects characteristic of the various education systems in the European space.

In most European education systems (European Commission, n.d.a), it is compulsory for schools to have a CPD (Continuous Professional Development) plan for the development of which the school principal, the management team or another specially appointed teacher is responsible - for the co-ordination of continuing vocational training / development activities.

In many countries (European Commission, n.d.b), higher authorities establish the priority themes or areas of continuing vocational training / development. Some educational systems (Vaz-Rebelo et al., 2015) provide financial support for teachers participating in certain CPD activities (Greece, Malta, the Netherlands). In other countries, teachers are given free time or paid leave to participate in CPD activities (Ireland, Greece, Spain, Italy, etc.) (European Commission, 2013; European Council \& European Commission, 2015).

Given that in many countries the effectiveness of initial and inservice teacher training programs is not at the desired level, the quality of education is affected, the interest and attractiveness of the teaching profession has declined, measures are needed to produce sustainable effects at the level of CPD and educational systems in particular, as well as at the level of society as a whole, and to give this profession the proper status (Enache, Petrescu, Gorghiu, \& Drăghicescu, 2017).

\section{Distinctive marks of continuing professional development (CPD) in Romania}

Continuing professional training of teachers in Romania is a very complex phenomenon, with influences on both individual and organizational level. Teachers participate in training programs (Dumitriu, Dumitriu, \& Timofti, 2014). They are required to participate regularly in lifelong learning programs so as to accumulate, at each consecutive 5 -year interval, at least 90 transferable professional credits. Courses differ in format, presentation, and content. More and more training courses are being promoted in the field of using new technologies in the educational process, but also those that do not involve physical presence such as online ones (Butnaru, 2016). 
Although more and more teachers are involved in training, this does not mean that training is not without challenges and difficulties. The main constraints on participation in lifelong learning (ISE, 2009) are of a financial, access and time nature. Thus, there are disadvantages in the participation of teachers in training courses for those under the age of 30, those with less didactic experience or those from rural areas. At the same time, some training programs have very high costs, preventing teachers from participating. Other difficulties are related to the inadequate placement of courses, in relation to the teachers' work schedule. Last but not least, the qualities of the trainers have an impact on the choice of training programs.

The endowment of teachers with professional competences in their initial and continuous training is also a priority for the Romanian educational system. Developing lifelong learning programs that genuinely improve teachers' skills, disseminate information about them and financial support should be ensured so that teachers can participate and enjoy this right free of charge.

\section{Research Aim}

In this paper, we want to present the results of a study that focused on the views of teachers regarding the education and training of teachers through continuous training programs and to capture their perceptions regarding the inequalities and the way in which those affect their continuous training, as well as to identify ways of combating and preventing this phenomenon in Romania at present.

At the same time, the purpose of this study is to identify new ways of organizing and conducting these continuous training programs, improving them by eliminating as far as possible all the sources that induce teachers' inequalities according to the needs of the direct beneficiaries and the general European-level educational practices.

\section{Research Methods}

In order to achieve the above mentioned objectives, we designed and applied, on a sample of $\mathbf{3 4 2}$ teachers from pre-university education (preschool, primary, secondary, and high school level), from Dâmbovița, Argeş, Prahova counties, and Bucharest city in Romania - participants in continuous training programs in the period 2016-2018, a questionnaire with 10 items out of which 8 with closed responses and two open-ended. It was applied in the context of continuous training activities, workshops and 
roundtables with the pre-university education staff that were graduates of a continuous training program. Data obtained from the survey-based questionnaire was processed by quantitative, statistical and mathematical analysis, being analyzed and subsequently correlated with qualitative assessments, following the study of the specialized literature and the debates attended by some of the respondents.

\section{Findings}

\subsection{Teachers' perceptions regarding the promotion of equal opportunities in the continuous training programs}

This refers to the extent to which the promotion of equal opportunities in the continuous training of teachers is achieved (figure 1). More than half of the teachers $(82 \%)$ appreciate that it is extremely important to be promoted the equal opportunities in the continuous training programs.

\section{$100.00 \%$}

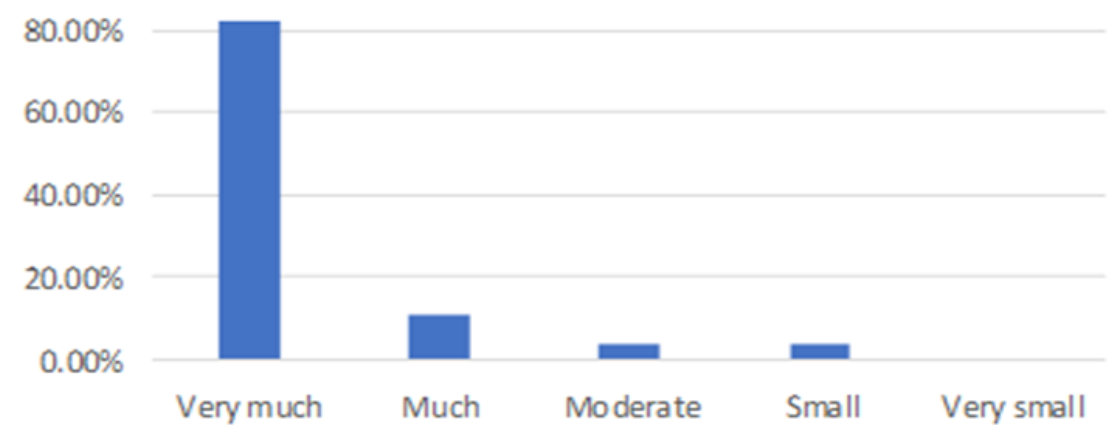

Figure 1. Teachers' feedback concerning of equal opportunities in the continuous training programs

\subsection{Types of training activities}

The following item aimed at identifying the main continuous training activities the teachers participated in. Thus, we find out that although most of the respondents initially stated that the training activity was important, few respondents chose all forms. However, most have chosen at least 2 or 3 types of training they have attended, which validates the importance of continuous training not only in respondents' perceptions, but also in reality.

The main courses where the teachers have participated are: training courses with the scope of developing the didactic, psycho-pedagogical, scientific, guidance, management skills. In the same time there was also 
courses related to conversion programs, courses that prepare them for the examination for didactic grades I and II.

\subsection{Ways of manifesting inequalities in continuous education}

Respondents believe that the manifestation of inequality in the field of continuous formation takes many forms. For example, inequality can mean the influence of some people on decisions, blockage in communication, the lack of material resources needed for training, the impossibility of equally benefiting projects and courses. Teachers also take into account unequal access to information on training, discrimination on certain criteria (ethnicity, social status), and ineffective communication between teachers and their trainers.

From the list of above-mentioned inequalities, $45 \%$ from the respondents considered, in the first place, that the lack of financial resources to sustain continuous training is responsible for the existence of these inequalities and $40 \%$ of them considered inefficient communication to be a barrier to access the lifelong learning programs.

The item asking respondents to identify the main issues they encounter in preventing or combating these inequalities is the one with the widest variety of responses. The distribution of responses can be seen in figure 2 .

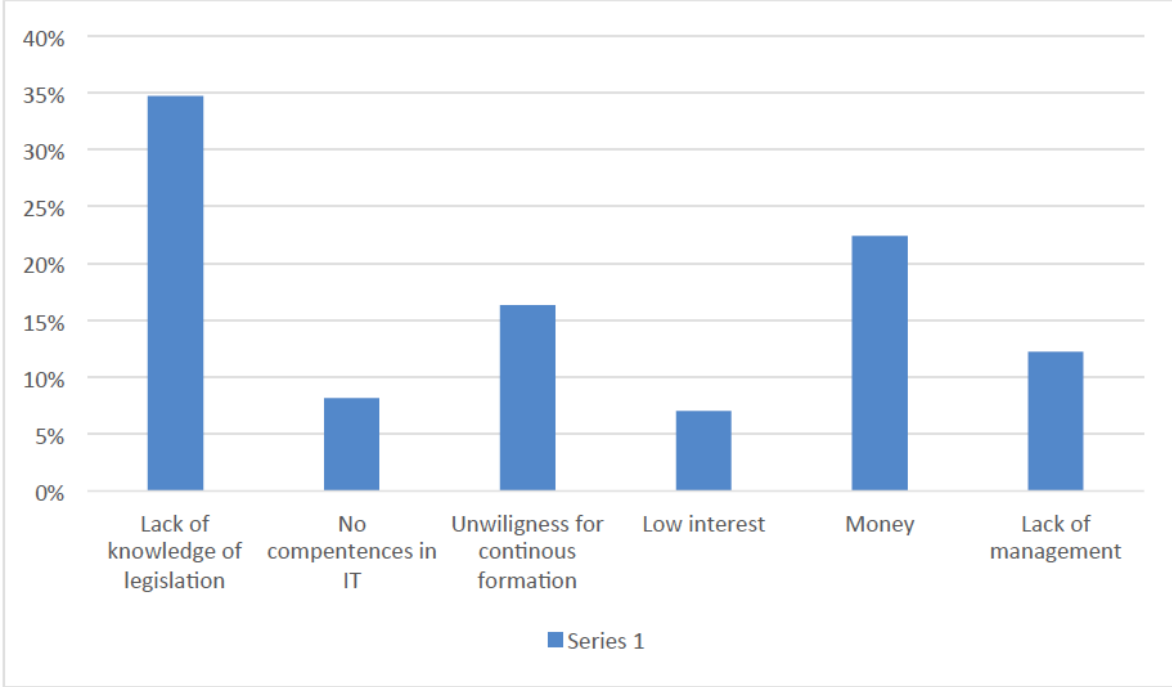

Figure 2. Teachers' feedback concerning the main issues encountered in preventing or combating the inequalities 


\subsection{Solution to combat the inequality phenomena}

In collecting solutions to prevent and combat the phenomenon of inequality in lifelong learning, we find out that most of the teachers referred to the correct and timely information on training programs. Teachers also believe that courses need to be held in centers close to their workplaces or home. For teachers is also very important to be taken into account their needs and interests in order to plan CPD courses or activities.

At the same time, respondents believe that several qualities of trainers and decision-makers in education are needed, namely: tolerance, understanding, lack of discrimination and prejudice, effective communication to ensure access to information, availability of training, and taking into account of learners' learning needs.

On the other hand, teachers feel the need for training programs to be funded by the government or why not, free of charge. In this context we recall that the lack of financial resources is very disadvantageous for the teachers who want to develop.

According to our results of the research we offer some general guidelines for the development of policies and practices regarding the continuous training of teachers in Romania. These include:

- To ensure educators can get the necessary pedagogical skills, knowledge, behaviors that will empower them to be effective;

- Secure adequate coordination, coherence and resources for teacher training and development;

- Strength the research and reflective practice skills of the teachers

- Making the teaching role to be more visible and recognized in the society

- Helping education to become professional.

\section{Conclusions}

Faced with the implicit changes of a knowledge society, teachers need to face a constant process of development and skills acquisition. Therefore, it is necessary to complete the initial psycho-pedagogical training and to be in a continuous process of development foe being able to have the necessary skills in a society that put emphasis on the knowledge.

Teachers face new roles and skills: with skills and abilities in new IT skills, counseling, intercultural education, integrated education, etc., and they need to push the limits of their knowledge acquisition through reflexive practice, through research and through a systematic commitment to lifelong learning as long as they are involved into a education process. Teacher 
training and education systems must provide them with the necessary opportunities.

All of those findings demonstrate that teachers are aware of the need for a new approach in promoting the promotion of equal opportunities in continuing teacher education.

Inequalities in the continuing training of teachers who have resulted from this research are found in other learning communities, such as: the lack of financial resources and the lack of communication between CPD providers and teachers (Vaz-Rebelo et al., 2015). Teachers also want to be taken into account their needs and interests in CPD courses (ISE, 2009; Mushayikwa \& Lubben, 2009).

The strategies regarding continuous teacher education should focus on a national strategy that introduces a criterion in lifelong learning programs - dissemination to be non-discriminatory, motivate teachers to participate in lifelong learning through areas as close as possible to their needs, develop through training values, behaviors and attitudes through which teachers promote equality of opportunity also among students (European Commission, 2018).

\section{References}

Butnaru, C. (2016). Coordonate actuale privind formarea continuă a cadrelor didactice [Current coordinates regarding the continuous training of teachers]. Univers pedagogic, 2(50), 97-101.

Dumitriu, C., Dumitriu, G., \& Timofti, I. C. (2014). Teachers' professional development and career advancement. Limitations of the current model of professional competences assessment, Procedia - Social and Behavioral Sciences, 116, 864 - 868. doi:10.1016/j.sbspro.2014.01.311

Enache, R. C., Petrescu, A. M. A., Gorghiu, G., \& Drăghicescu, L. M. (2017). Present and perspectives in the teachers' continuous professional training in Romania. LUMEN EDU International Scientific Conference, Education, Quality and Sustainable Development, 2017, November 2223. Bucharest, Romania.

European Commission. (2013). Key data on teachers and school leaders in europe. Eurydice. Retrieved from https://edudoc.ch/record/106850/files/151EN.pdf

European Commission. (2015). Education and Training Monitor 2015, Country analysis. Retrieved from https://ec.europa.eu/assets/eac/education/tools/docs/2015/monitor15vol-2 en.pdf 
European Commission. (2018). National student fee and support systems in european higher education - 2018/19. Eurydice - Facts and figures. Luxembourg: Publications Office of the European Union. Retrieved from https://eacea.ec.europa.eu/nationalpolicies/eurydice/sites/eurydice/files/fee_support_2018_19_report_en.pd $\underline{\mathrm{f}}$

European Commission. (n.d.a). Eurydice. Retrieved from https://eacea.ec.europa.eu/national-policies/eurydice/content/continuing professional-development-teachers-working-early-childhood-and-schooleducation-34 en

European Commission. (n.d.b). Key action 2: Cooperation for innovation and the exchange of good practices. Retrieved from https://ec.europa.eu/programmes/erasmusplus/book/export/html/326 en

European Council, \& European Commission. (2015). New priorities for European cooperation in education and training - 2015/C 417/04). Retrieved from https://eur-lex.europa.eu/legalcontent/EN/TXT/PDF/?uri=CELEX:52015XG1215(02)\&from=EN

European Council. (2009). The Conclusions of the Council from May the $12^{\text {th }}$, 2009, concerning a strategic frame for European cooperation in the area of education and professional development - "ET 2020". Retrieved from http:/ / eur-lex.europa.eu/legal-content/RO/TXT/PDF/?uri=CELEX: $\underline{52009 X G 0528(01) \& \text { from }=\mathrm{RO}}$

Institutul de Științele Educației (ISE). (2009). Formarea profesională continuă în România [Continuing vocational training in Romania]. Retrieved from http://nou2.ise.ro/wp-content/uploads/2012/08/formare continua.pdf

Mushayikwa, E., \& Lubben, F. (2009). Self-directed professional development Hope for teachers working in deprived environments? Teaching and Teacher Education, 25(3), 375-382. doi:10.1016/j.tate.2008.12.003

Vaz-Rebelo, P., Swennen, A., Golan, M., Van der Klink, M., Van Velzen, C., De Lima, M. P., Vermel, J., Barreira, C., Pessoa, M., \& Gomes, C. (2015). Teacher educators policy, practice and research bringing together policy, practice, and research. Proceedings, 4th ATEE Winter Conference-University of Coimbra, ATEE. Brussels, Belgium: Association for Teacher Education in Europe. 